The $5^{\text {th }}$ International Conference on Family Business and Entrepreneurship

\title{
WEBSITE AND PRICING STRATEGY DEVELOPMENT: A BUSINESS COACHING AT LOCAL SME
}

\author{
Lery Anggityo ${ }^{1 *}$, Lily Sudhartio ${ }^{2}$ \\ ${ }^{1,2}$ Faculty of Economic and Business, Universitas Indonesia \\ Corresponding author:leryanggityo0210@gmail.com
}

\begin{abstract}
:
Small and medium-sized enterprises (SME) make a very large contribution to Indonesia's gross domestic product (GDP) and absorb a lot of labor from the entire workforce. Unfortunately, many SMEs face so many problems in their business operation. Whether the issues arising from internal factors such as management or external factors such as the COVID-19 pandemic, therefore they need support and insights from the experts on how to solve their problems. The current business coaching was conducted in PT Bumi Perkasa Internasional, a small business located in Bekasi, West Java and is engaged in the manufacturing industry with the scope of expertise in the Dust Collector System. The Business Coaching used a qualitative approach that mapping the real conditions and problems of SMEs, then propose solutions, and implement them for SMEs improvement. this method requires two types of data, primary data and secondary data Primary data collection technique is obtained by interview, observation and documentation. Secondary data was obtained by conducting a literature study related to information on the manufacturing industry, SMEs itself, finance, marketing, operations management and human resource management The result shows that the company did not have an effective website as its marketing channel and an unfavorable pricing strategy, indicated by no leads originating from the company's website and inability to profit from the project. The business coaching suggests the management to develop their website and pricing strategy to improve their conditions.
\end{abstract}

Keywords: Business coaching, SME, B2B Marketing, Website for B2B, Pricing Strategy.

\section{Introduction}

Economic development of a country is an important pillar for the implementation of the development process in all other fields. A country that has successful economic development is marked by the high income per-capita of its people. The industrial sector is one of the sectors that plays an important role in national development. Small and medium-sized enterprises (SMEs) account for the majority of businesses worldwide and are important contributors to job creation and global economic development. They represent about $90 \%$ of businesses and more than $50 \%$ of employment worldwide (Worldbank, 2019). In developed countries, SMEs commonly follow "niche strategies" using high product quality, flexibility, and responsiveness to customer needs as a means of competing with large-scale mass producers (Hallberg, 2000).

In Indonesia, SMEs are one of the industries that provide improvement to the economy. Based on data from the Ministry of Cooperatives and Small and Medium Enterprises of the Republik Indonesia (Kemenkopukm, 2019), it can be said that the growth of SMEs in Indonesia has always increased every 
year from 2015 to 2019. This growth will certainly increase the Indonesian economy. However, as the number of SMEs increases, the competition will also increase. In order to maintain sustainability, every MSME must have its own charm, provide a competitive advantage that its competitors do not have, be able to retain its customers and be able to increase its customers by expanding the target market as one way.

But it is not easy, it takes a good marketing strategy and marketing tools in order to get new customers and retain old customers. There are also many MSME owners who do not have good marketing competence and work alone, so they have difficulty running a business. To be able to survive, SMEs owners still have to do marketing that is suitable for their business growth even though they do not have the resources or a supporting operational structure like those of large companies (Gilmore, Audrey, 2011).

In a business, the buying process on Business-to-Business (B2B) is more complex than Business-toConsumer (B2C). Because the stages that B2B organizations generally take on the buying process are sequential starting from problem recognition, general description of need, product specifications, supplier search, acquisition and analysis of proposals, supplier selection, selection of order routines, and performance reviews (Michael Hutt, 2013). The complexity of the buying process in B2B has resulted in the importance of good personal selling in the sales process and in its customer relationships.

In addition, the quality of information and the credibility of the website greatly affects the experience of consumers when searching for information on B2B websites (McLean, 2017). A website is a place where a company can operate so that its consumers can collect information related to products or services provided by the company and have the potential to make purchases (McPheat, 2011). Besides that, price has a direct impact on company profits, a small percentage increase in price can result in a large percentage increase in profitability (Kotler \& Keller, 2016). That's why pricing is one of the most important issues many marketing executives face, and many companies don't handle pricing very well.

PT Bumi Perkasa Indonesia is one of the SMEs engaged in the service industry and machine / system products with a scope of expertise in the Dust Collector System targeting B2B consumers. In the B2B marketing mix, there are prices and promotions which are important pillars in the marketing strategy. However, PT Bumi Perkasa Internasional has problems in determining the price of its products, indicated by the small profit in each project. And the ineffectiveness of the corporate website as a marketing channel that can actually be very helpful to acquire new customers. To solve this problem, a business coaching study will be conducted using a coaching program that focuses on developing website and pricing strategy that will be carried out at PT Bumi Perkasa International.

\section{Literature Review}

\section{$B 2 B$ Marketing}

B2B (business to business) markets are markets for products and services, from local to international, purchased by a business company, government or other institution, for incorporation (for example ingredient materials or components), for consumption (for example process materials, office supplies, or consulting services), for use (for example equipment installation), or for resale (Michael Hutt, 2013). The purchasing process is also more complex when compared to $\mathrm{B} 2 \mathrm{C}$, where the stages that organizations generally carry out in the buying process are sequential starting from problem recognition, general description of need, product specifications, supplier search, acquisition and analysis of proposals, supplier selection, selection of order routines, and performance review (Michael Hutt, 2013). Work in industrial marketing has been concentrated on the first approach that assesses value, in the context of trade, as a costbenefit trade-off relative to a supplier's offer, perceived by decision-makers in the client organization (Eggert and Ulaga, 2002; Ulaga and Chacour, 2001).

The perceived value may, therefore, arise from, say, the product performance, the support service, the employees' competence, or the supplier's capacity to innovate (Corsaro and Snehota, 2010; Ulaga and Eggert, 2006). At the time of the buying process it also involves many parties where these parties can have their respective roles, namely the roles of users (people who use), gatekeepers (who control information), influencers (who influence purchasing decisions), deciders (who actually decide), and buyers (who formally have the power to choose suppliers) (Michael Hutt, 2013). Due to the complexity of the buying process in 
B2B which involves many parties, a salesperson plays an important role in maintaining contact with consumers through personal selling (Wei-Lin and Wang, 2017).

\section{Website for $B 2 B$}

Website is a part of digital marketing. Digital marketing is digital technology where it is able to create integrated communication, has a target, and is measurable, which will help companies to obtain and retain customers while building deeper relationships (Smith, 2007). Digital marketing has a number of goals called 5Ss of marketing, the five goals / benefits of digital marketing or e-marketing are: (Dave Chaffey, 2016)

1. Sell- Grow Sales - to expand distribution channels for consumers who cannot be served offline.

2. Serve - Add Value - to provide added value to consumers or inform product development with online chat and feedback.

3. Speak - Get Closer to Customer - to create two-way communication by using websites, e-mail, and polls, also trying to talk to reach key influencers using e-PR.

4. Save - Save Cost - by using online communication such as e-mail, sales, and transaction services can reduce staff costs, printing, and shipping costs (via digital).

5. Sizzle - Extend the Brand Online - the company can provide new propositions and new experiences for customers.

A website is a place where a company can operate so that its consumers can gather information related to products or services provided by the company and have the potential to make purchases (McPheat, 2011). The website is also a form of online marketing, where if the design of the company's site is properly arranged, the company website will be easily found on search engines like Google and will be accessible to consumers who have potential purchases (McPheat, 2011). Marketers can increase the ranking of their ads on search results pages by increasing their quality score to make it more significant and therefore more compatible with search engines (Sen, 2005)

$7 \mathrm{C}$ 's framework is a framework that can be used by companies as a guide for designing customer interfaces (CIs) when creating a website where interfaces are on a website is a virtual representation of the value chosen by the company to be displayed to consumers. In 7C's Framework there are two concepts that can help the development of the system on how to use all 7C's elements simultaneously, namely first is fit which is described by how much influence each element of $7 \mathrm{C}^{\prime} \mathrm{S}$ has on the business model, and the second is reinforcement based on the level of consistency of each element. The 7C's framework are context, content, community, customization, communication, connection and commerce (Rayport \& Jaworski, 2001). The results from McLean's study (2017) shows that the quality of the information on the website as well as the credibility of the website has a significant effect on the success of the search. Customers should perceive the website as being credible and containing good quality information (McLean, 2017).

\section{Pricing Strategy}

For every product, the company has to choose a price. But determining the price can take many ways. Most importantly, it should follow a predetermined strategy. 3 major pricing strategies can be identified: Customer value-based pricing, cost-based pricing and competition-based pricing (Maximilian. 2015). According to (Hinterhuber and Liozu, 2012) pricing of goods and services determines the level of profitability and the general liquidity experienced by firms. Similarly, (Wuollet, 2013) who acknowledged that the different pricing strategies of cost-based pricing, competition-based pricing and customer valuebased pricing predict the amount of revenue that the firm can be able to generate over the long-term.

Which one should you select? Whatever price you choose, it will fall somewhere between one that is too high to generate any demand and one that is too low to cover your expenses. It is somewhere between a price ceiling and a price floor. Customers' perceptions of the product's value set the price ceiling. If customers perceive that the product's price is higher than its value, they will not buy the product. On the other extreme, product costs set the price floor. If the product's price is lower than its costs, the company will make losses (Maximilian. 2015). Price is the amount of money charged for goods or services, or the 
amount of value that customers exchange for the benefit of owning or using goods or services (Kotler, 2016). Historically, price has been the main factor influencing buyer choice. little research is available that addresses the value of one pricing strategy over another" (Myers, 2004).

However, in recent decades, the non-price factor has grown in importance. Even so, price remains one of the most important elements that determine market share and company profitability. Pricing is the number one problem many marketing executives face, and many companies don't handle pricing very well. Price has a direct impact on company profits (Kotler, 2016). According to Milton (1987), a budget is a plan expressed in financial and other quantitative terms. In another perspective, (Soemardjo, 1980) said that the budget is any financial plan which is an estimate of activities and as a control. The budget is said to be important for every business because it has several functions such as: (Gunawan, 2013)

- Planning Function: When compiling a work program

The budget as a planning tool must pay attention to the relationship between one budget and another, besides that, another important aspect of planning is to use the budget in planning the available funds as efficiently as possible.

- Coordination Function: During program implementation.

The budget as a guide for the implementation of the work, meaning that before the work is carried out, it must first obtain approval from the authorities (especially in terms of finance). Work is approved to be carried out if there is a budget or does not deviate from the budget

- Supervision Function: At the time of reassessment

The budget is a means of supervision or control which means evaluating (assessing) the implementation of work, by comparing the realization with the plan (budget) and taking corrective actions if deemed necessary or if there are adverse deviations.

Customer value-based pricing is based on the perception of price determination of the value of the buyer, not the seller's expense. Effective customer-oriented pricing involves understanding how much value consumers place on the benefits they receive from the product and setting a price that captures that value. Cost-based pricing is the pricing based on cost of production, distribution and sale of products plus a fair rate of return for the effort and risk. The costs calculated here are in the form of fixed costs, which are costs that do not differ from production or sales levels. Competition-based pricing involves pricing based on competitor's strategy, costs, pricing, and market offerings. Consumers will base their judgment about the value of the product on the price competitors charge for similar products (Kotler, 2016).

Companies usually adjust their base price to take account of different customer differences and changing circumstances. A discount sale consists in selling a given set of items at a reduced price for a limited period. Some examples are proposed in (Bolton, 1989), (Blattberg and Neslin, 1990), (Bemmaor and Mouchoux, 1991). This reduction should generate enough supplementary sales to compensate the reduction in income. However, this is rarely the case. Few companies realize the true discount cost. When a product discount is offered for a given period, it applies to all sales, which often leads to disastrous consequences. The following are seven price adjustment strategies summarized 
Table 1. Price Adjustment Strategies

\begin{tabular}{|c|c|}
\hline $\begin{array}{l}\text { Strategy \& } \\
\text { Aspects }\end{array}$ & Description \\
\hline $\begin{array}{l}\text { Discount and } \\
\text { allowance pricing }\end{array}$ & $\begin{array}{l}\text { Reducing prices to reward customer feedback such as purchasing volume, paying } \\
\text { early, or promoting a product. }\end{array}$ \\
\hline $\begin{array}{l}\text { Segmented } \\
\text { pricing }\end{array}$ & Adjust prices to allow for differences in customers, products, or locations. \\
\hline $\begin{array}{l}\text { Psychological } \\
\text { pricing }\end{array}$ & $\begin{array}{l}\text { Pricing that takes price psychology into account, not just economics. Price is used } \\
\text { to say something about a product. }\end{array}$ \\
\hline Reference prices & Prices are remembered by buyers and refer to when they see a particular product. \\
\hline $\begin{array}{l}\text { Promotional } \\
\text { pricing }\end{array}$ & $\begin{array}{l}\text { Pricing products temporarily below their selling price, and sometimes even below } \\
\text { cost, to increase short-term sales. }\end{array}$ \\
\hline $\begin{array}{l}\text { Geographical } \\
\text { pricing }\end{array}$ & Set prices for customers located in different parts of the country or the world. \\
\hline $\begin{array}{l}\text { FOB-origin } \\
\text { pricing }\end{array}$ & $\begin{array}{l}\text { A geographic pricing strategy whereby goods are placed free of charge on a } \\
\text { carrier vessel; the customer pays the freight from the factory to the destination. }\end{array}$ \\
\hline $\begin{array}{l}\text { Uniform- } \\
\text { delivered pricing }\end{array}$ & $\begin{array}{l}\text { A geographic pricing strategy in which the company charges the same price plus } \\
\text { freight to all customers, regardless of location. }\end{array}$ \\
\hline Zone pricing & $\begin{array}{l}\text { A geographic pricing strategy in which a company defines two or more zones. All } \\
\text { customers in a zone pay the same total price; the further away the zone is, the } \\
\text { higher the price. }\end{array}$ \\
\hline $\begin{array}{l}\text { Base-point } \\
\text { pricing }\end{array}$ & $\begin{array}{l}\text { A geographic pricing strategy in which the seller designates multiple cities as a } \\
\text { base point and charges all customers shipping costs from that city to the customer. }\end{array}$ \\
\hline $\begin{array}{l}\text { Freight- } \\
\text { absorption pricing }\end{array}$ & $\begin{array}{l}\text { A geographic pricing strategy in which sellers absorb all or part of the freight } \\
\text { costs to get the business they want. }\end{array}$ \\
\hline $\begin{array}{l}\text { Dynamic and } \\
\text { online pricing }\end{array}$ & $\begin{array}{l}\text { Continuously adjusting prices to meet the characteristics and needs of the } \\
\text { customer and individual situations. }\end{array}$ \\
\hline $\begin{array}{l}\text { International } \\
\text { pricing }\end{array}$ & $\begin{array}{l}\text { Adjusting prices for international markets, firms adjust their prices to reflect local } \\
\text { market conditions and cost considerations. }\end{array}$ \\
\hline
\end{tabular}

Source: Kotler \& Keller (2016)

\section{Research Method}

In its implementation, Business Coaching is divided into several stages carried out by the author starting with data collection, data analysis, problem identification, problem solving, and implementation. This Business Coaching is a qualitative case study conducted at PT Bumi Perkasa Internasional, and has several stages as follows: 


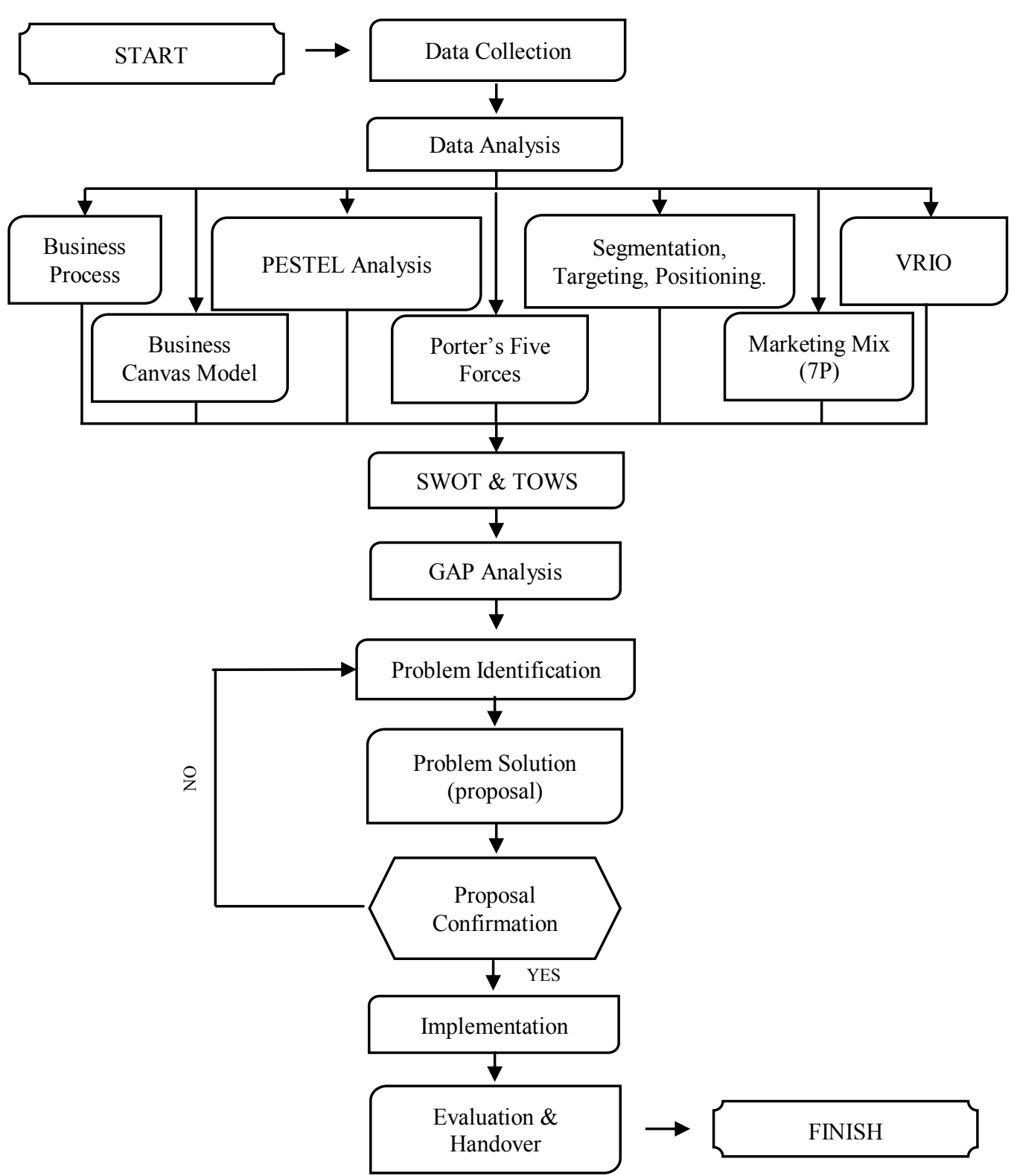

Figure 1. Stages of the Business Coaching Process

(Source: Authors, 2020)

Data collection carried out in this Business Coaching uses qualitative methods. Qualitative research is an interpretation technique to describe, decode, translate and get a meaning, and find something more or less in natural phenomena in the social world (Cooper, 2006). In this research method will focus on an organization or company, its business problems, and the factors of the problem. Collecting data in this method requires two types of data, primary data and secondary data.

Primary data is data obtained and obtained through direct interaction with the object of research, namely PT Bumi Perkasa Internasional. Primary data collection technique is by interview, observation and documentation. Secondary data was obtained by conducting a literature study related to information on the manufacturing industry, MSMEs, finance, marketing, operations management and human resource management to help resolve the gap and Pareto problems that occurred at PT Bumi Perkasa Internasional. After getting the required data, the data is analyzed to identify problems and find the best solution. According to Malhotra (2010), there are three general steps that can be taken to analyze qualitative data, namely: 


\section{Data Reduction}

In this step after collecting the data that we need for the research, the data is selected by choosing which data will be reduced to emphasize or summarize the data from the research results, the data to be selected are data from interviews, observations, and documentation conducted by the author.

\section{Data Display}

In this step, the reduced data is converted into a visual interpretation in the form of diagrams, tables, graphs, and narratives. The view is intended to help illustrate data patterns and relationships or relationships between data. The visual interpretation of the results of this data selection is in the form of PESTEL analysis. PESTEL analysis is usually used to analyze and understand the overall picture of the company's external environment where the external factors include Politic, Economy, Social, Technology, Legal, and Environmental (Thompson et al., 2016). Porter's five forces analysis, Michael Porter developed a fiveforces model of competition analysis tool which aims to identify and analyze the competitive conditions of the business environment in a business unit (Gamble, 2015). Business Model Canvas, the concept of the business model canvas can be a language that makes it easy to describe and manipulate business models to create alternative strategies because without such a language, it will be difficult to assume a business model and innovate (Osterwalder, Pigneur, 2010). STP (segmenting, targeting, positioning), Attention to market segmentation is needed in order to penetrate the target market of an MSME and company. After the market segment is seen, the producer decides which segment has the greatest opportunity to become the target market. Furthermore, producers will be able to develop products to meet market segments in accordance with the intended target market to be able to position products with competitors according to the value offered. Marketing mix (7P), is a set of marketing tools that are combined by the company to produce the desired response in the target market (Kotler \& Keller, 2016). VRIO analysis is one of the methods of internal analysis that aims to evaluate the company's resources and capabilities in order to determine the potential for competitive advantage (Barney \& Hesterly, 2008). SWOT analysis is a method that aims to identify the factors determining a company's strategy based on elements of strengths, weaknesses, opportunities, and threats (Gurel and Tat, 2017). Then perform a TOWS matrix analysis, which aims to improve the company's position among other companies.

\section{Conclusion Drawing and Verification}

The final step is drawing conclusions and levers. The conclusion is obtained by discussing and understanding the data that has been presented through GAP analysis and Pareto analysis and is used as information for business development purposes by producing a business model.

\section{Result and Discussion}

Based on the results of the analysis in Figure 2, there are two plans that will be prioritized in this study. The plan is Website Improvement and Pricing Strategy because it has an accumulated impact of $50.36 \%$ on Pareto analysis. How to manage a sales force that will help from staff recruitment to personal selling, HR training in the form of skills development planning through expertise certification such as K3/HSE certification training, ISO, welder professional training and others, and also investor search has not been carried out in this business coaching because managing sales force, training of human resources, and investor search requires considerable time and considerable expense, which, according to the narrative of the owners of SMEs are also not able to meet it in the near future. 


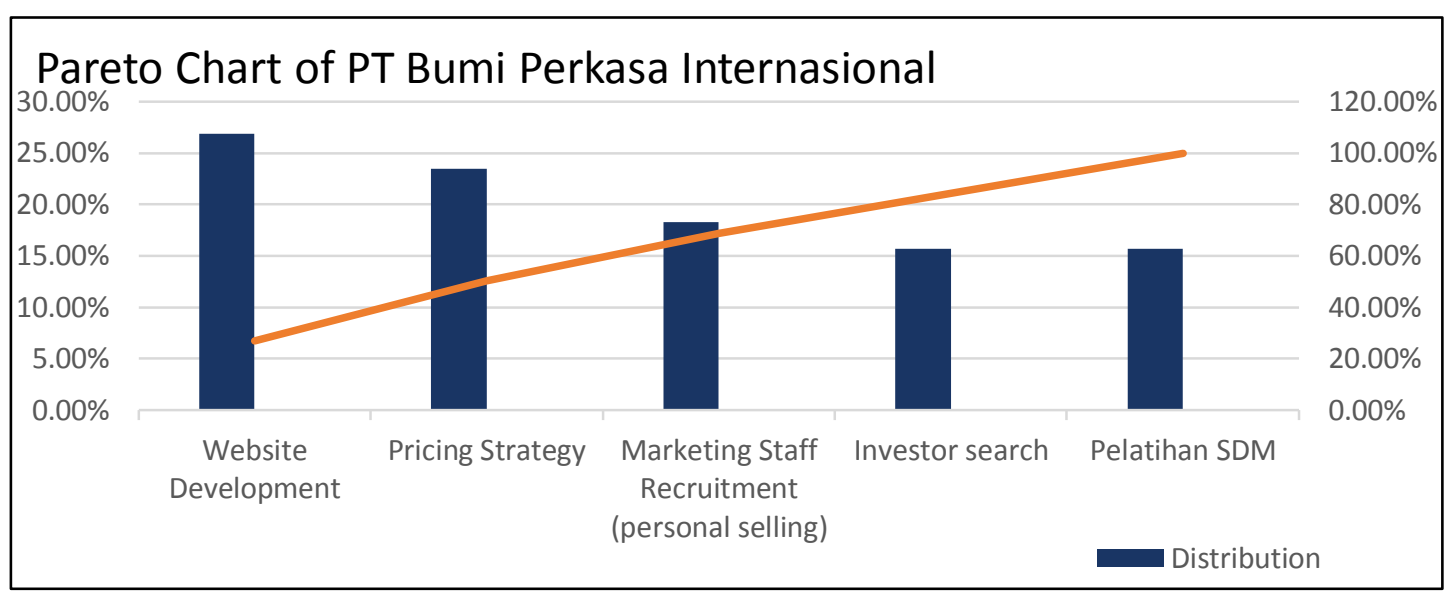

Figure 2. Pareto Chart of PT Bumi Perkasa Internasional

(Source: Authors, 2020)

\section{Website Development}

According to McPheat (2011), the website is a place where companies can operate so that consumers can collect information related to products or services provided by the company and have the potential to buy. This website is also a form of online marketing, if the design of the company's website structure is reasonable, the company's website can be easily found on search engines (such as Google), and consumers who have potential purchasing power can also visit the website. In addition, based on a study conducted by Graeme J McLean (2016), it was found that when looking for information on B2B websites, the quality of information and website reputation greatly affect consumer experience.
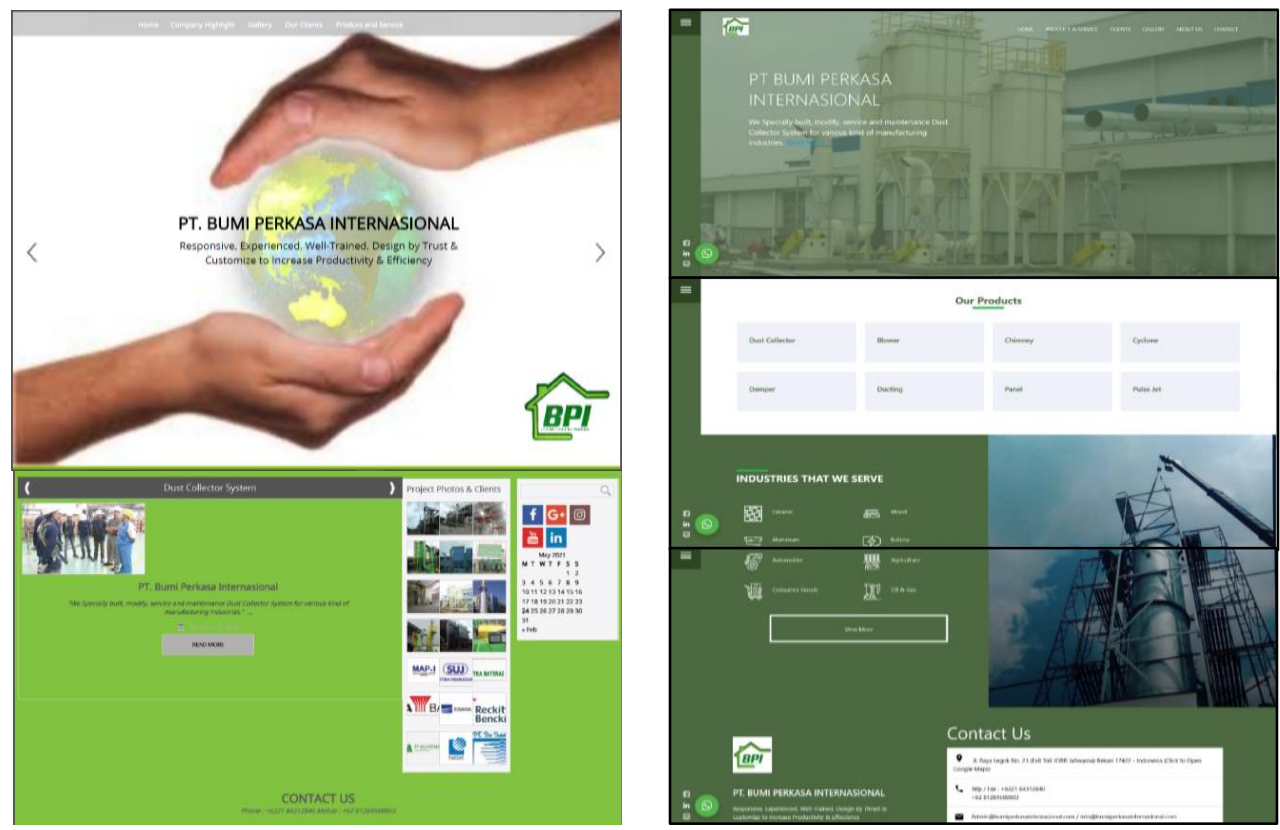

Figure 3. Before and After Website Development of PT. Bumi Perkasa Internasional (Source: Authors, 2021) 
However, although the website of PT Bumi Perkasa Internasional has long been created, the site has not provided more benefits to the company. From the results of interviews and observations, it is known that the website is not managed properly, although there is additional content, it is only limited to adding new projects that have been completed and it has also been a very long time since they last did it. In addition, in terms of design and information that gives a positive impression to consumers, it has not been changed since the company's website was first created, so it is no longer in accordance with the design criteria and information for current consumers.

From the results of the discussion, it was found that there were deficiencies or gaps that could be used as benchmarks for improvement. First, the graphic design display is less attractive, there are no contacts available to contact MSMEs, and the explanation of the product information provided is still very little and not visually appealing. Then after knowing the shortcomings, the next step is to design a new website using $7 \mathrm{C}$ 's framework. 7C's framework is a framework that companies can use as a guide for designing customer interfaces (CI) when creating websites where the interface on the website is a virtual representation of the values the company chooses to display to its consumers (Rayport \& Jaworski, 2001).

\section{Pricing Strategy}

According to Kotler (2016), price is the amount of money charged for goods or services, or the amount of value that customers exchange for the benefit of owning or using goods or services. The customer's perception of the value of the product determines the upper limit of its price. If customers feel that the product's price is greater than its value, they will not buy the product. There are three major strategies in determining prices, namely Customer value-based pricing, Cost-based pricing, and Competition-based pricing.

PT Bumi Perkasa Internasional applies cost-based pricing in determining the price of its products. Because the type of product is customized where the product is in accordance with the needs of each customer, the price of each product that is made is also different. In addition, it is said that PT Bumi Perkasa Internasional issues competitive prices, where the price formation process occurs 2 to 3 times. In the first offer made by MSMEs, and next is the bid price after the bargaining process between MSMEs and customers.

However, based on the results of interviews and observations, it is known that PT Bumi Perkasa Internasional has a small percentage of gross margin on the price of its products so that according to the owner in the last 3 years each year only has a small profit from selling its products and in 2019 it can be said that the profit obtained from no product sales. This is acknowledged by the owner due to the RAB (Expense Budget Plan) which does not have a good preparation, format, and method, thus affecting the price offered to be less profitable.

After cross-checking and analyzing the RAB (Expense Budget Plan) made by this MSME for each offer, it was found that there were deficiencies or gaps that could be used as benchmarks for improvement. The first thing is that Fixed Costs are not taken into account every year, this greatly affects the price determination of a product that has a cost-based pricing strategy. Then the second is the calculation of Variable Costs which is not adjusted to the actual price, where the price of the variable costs is directly raised without any careful calculation and without any cross-check of the actual price. Then there is no calculation for unexpected costs from each RAB calculation (Expense Budget Plan) made for every offer given to customers for their products. And the last is the format is not neat, so it can't be re-evaluated. 
Table 2. Example of New Fixed Cost Format of PT Bumi Perkasa Internasional

\begin{tabular}{|c|c|c|c|c|c|c|}
\hline No & Peralatan dan Investasi & Satuan & $\begin{array}{l}\text { Umur } \\
\text { (Tahun) }\end{array}$ & Harga Satuan & Jumlah Biaya & $\begin{array}{c}\text { Penyusutan Per } \\
\text { Tahun } \\
\end{array}$ \\
\hline 1 & Cutting Plasma & 1 & 10 & $16.000 .000,00$ & $16.000 .000,00$ & $1.600 .000,00$ \\
\hline 2 & Welding Machine & 12 & 5 & $3.500 .000,00$ & $42.000 .000,00$ & $8.400 .000,00$ \\
\hline 3 & Co Machine Welding & 2 & 5 & $9.000 .000,00$ & $18.000 .000,00$ & $3.600 .000,00$ \\
\hline 4 & Bor Magnet & 2 & 5 & $5.000 .000,00$ & $10.000 .000,00$ & $2.000 .000,00$ \\
\hline 5 & Bor Machine & 12 & 2 & $2.000 .000,00$ & $24.000 .000,00$ & $12.000 .000,00$ \\
\hline 6 & Gerind Machine & 10 & 2 & $1.500 .000,00$ & $15.000 .000,00$ & $7.500 .000,00$ \\
\hline 7 & Mesin Roll & 1 & 5 & $30.000 .000,00$ & $30.000 .000,00$ & $6.000 .000,00$ \\
\hline 8 & Chain Block Cap & 10 & 5 & $2.500 .000,00$ & $25.000 .000,00$ & $5.000 .000,00$ \\
\hline 9 & CNC Cutting Machine & 1 & 5 & $75.000 .000,00$ & $75.000 .000,00$ & $15.000 .000,00$ \\
\hline 10 & Air Flow Meter & 2 & 10 & $8.000 .000,00$ & $16.000 .000,00$ & $1.600 .000,00$ \\
\hline 11 & Vibrating Level Meter & 1 & 10 & $21.000 .000,00$ & $21.000 .000,00$ & $2.100 .000,00$ \\
\hline 12 & Temperature Meter & 2 & 10 & $3.000 .000,00$ & $6.000 .000,00$ & $600.000,00$ \\
\hline 13 & Pilot Meter & 1 & 10 & $25.000 .000,00$ & $25.000 .000,00$ & $2.500 .000,00$ \\
\hline 14 & Safety Worker & & 1 & & $16.500 .000,00$ & $16.500 .000,00$ \\
\hline 15 & $\begin{array}{l}\text { Gaji Manajemen \& } \\
\text { karyawan kantor }\end{array}$ & & 1 & & $1.128 .000 .000,00$ & $1.128 .000 .000,00$ \\
\hline 16 & $\begin{array}{l}\text { Gaji karyawan } \\
\text { lapangan }\end{array}$ & & 1 & & $525.000 .000,00$ & $525.000 .000,00$ \\
\hline 17 & $\begin{array}{l}\text { Domain \& hosting } \\
\text { Website }\end{array}$ & & 1 & & $1.950 .000,00$ & $1.950 .000,00$ \\
\hline 18 & Listrik & & 1 & & $75.000 .000,00$ & $75.000 .000,00$ \\
\hline 19 & Telpon \& wifi & & 1 & & $6.000 .000,00$ & $6.000 .000,00$ \\
\hline 20 & Lingkungan & & 1 & & $12.000 .000,00$ & $12.000 .000,00$ \\
\hline 21 & Tanah & & 1 & & $55.000 .000,00$ & $55.000 .000,00$ \\
\hline 22 & Bangunan & & 5 & & $60.000 .000,00$ & $12.000 .000,00$ \\
\hline 23 & $\begin{array}{l}\text { Peralatan Kerja } \\
\text { Lainnya }\end{array}$ & & 5 & & $132.000 .000,00$ & $26.400 .000,00$ \\
\hline Total & & & & & $2.334 .450 .000,00$ & $1.925 .750 .000,00$ \\
\hline
\end{tabular}

Source: Authors (2021) 
Table 3. Example of New Variable Cost Format of PT Bumi Perkasa Internasional

\begin{tabular}{|c|c|c|c|c|c|c|c|}
\hline \multirow{2}{*}{ Fungsional } & \multirow{2}{*}{$\begin{array}{c}\text { Bahan Baku (Material) } \\
\text { dan Pelengkap }\end{array}$} & \multicolumn{4}{|c|}{ Dust Collector Tipe A } & \multirow{2}{*}{ Overhead } & \multirow{2}{*}{$\begin{array}{c}\text { Total Biaya } \\
\text { Variabel }\end{array}$} \\
\hline & & & nlah & Biaya Per Unit & Total Biaya & & \\
\hline \multirow[t]{9}{*}{ Material } & Plate MS $4 \mathrm{~mm}$ & 48 & Lembar & $1.225 .000,00$ & $58.800 .000,00$ & $10 \%$ & $64.680 .000,00$ \\
\hline & Plate MS $6 \mathrm{~mm}$ & 8 & Lembar & $1.550 .000,00$ & $12.400 .000,00$ & $10 \%$ & $13.640 .000,00$ \\
\hline & Plate Strip $75 \times 9 \mathrm{~mm}$ & 24 & Batang & $260.000,00$ & $6.240 .000,00$ & $10 \%$ & $6.864 .000,00$ \\
\hline & $\mathrm{L} 75 \times 75 \times 7 \mathrm{~mm}$ & 24 & Batang & $550.000,00$ & $13.200 .000,00$ & $10 \%$ & $14.520 .000,00$ \\
\hline & Shaft As Blower & 8 & Batang & $1.750 .000,00$ & $14.000 .000,00$ & $10 \%$ & $15.400 .000,00$ \\
\hline & Pulley & 16 & Unit & $4.750 .000,00$ & $76.000 .000,00$ & $10 \%$ & $83.600 .000,00$ \\
\hline & Bearing Plumer Block & 16 & Unit & $6.500 .000,00$ & $104.000 .000,00$ & $10 \%$ & $114.400 .000,00$ \\
\hline & Motor & 8 & Unit & $44.000 .000,00$ & $352.000 .000,00$ & $10 \%$ & $387.200 .000,00$ \\
\hline & V-Belt & 8 & Unit & $1.600 .000,00$ & $12.800 .000,00$ & $10 \%$ & $14.080 .000,00$ \\
\hline \multirow[t]{7}{*}{ Consumable } & Kawat Las Rb $3.2 \mathrm{~mm}$ & 200 & $\mathrm{Kg}$ & $25.000,00$ & $5.000 .000,00$ & $10 \%$ & $5.500 .000,00$ \\
\hline & Kawat Las Lb $3.2 \mathrm{~mm}$ & 80 & $\mathrm{Kg}$ & $40.000,00$ & $3.200 .000,00$ & $10 \%$ & $3.520 .000,00$ \\
\hline & Batu Gerinda Poles & 80 & Pcs & $17.500,00$ & $1.400 .000,00$ & $10 \%$ & $1.540 .000,00$ \\
\hline & Batu Gerinda Potong & 120 & Pcs & $30.000,00$ & $3.600 .000,00$ & $10 \%$ & $3.960 .000,00$ \\
\hline & Wire Brush & 16 & Pcs & $275.000,00$ & $4.400 .000,00$ & $10 \%$ & $4.840 .000,00$ \\
\hline & LPG \& Gas & 8 & Lot & $1.000 .000,00$ & $8.000 .000,00$ & $10 \%$ & $8.800 .000,00$ \\
\hline & Baut, Mur dan Ring & 400 & Pcs & $3.500,00$ & $1.400 .000,00$ & $10 \%$ & $1.540 .000,00$ \\
\hline \multirow[t]{3}{*}{ Operasional } & shipping & 1 & Unit & $15.000 .000,00$ & $15.000 .000,00$ & $10 \%$ & $16.500 .000,00$ \\
\hline & Over Time & 640 & HOK & $250.000,00$ & $160.000 .000,00$ & $10 \%$ & $176.000 .000,00$ \\
\hline & Total & & & & $851.440 .000,00$ & & $936.584 .000,00$ \\
\hline
\end{tabular}

Source: Authors (2021)

Table 4. New Pricing Strategy Format of PT. Bumi Perkasa Internasional

\begin{tabular}{|c|c|c|c|c|c|}
\hline \multicolumn{6}{|c|}{ Final Pricing } \\
\hline $\begin{array}{l}\text { Target unit } \\
\text { sales } \\
\text { pertahun }\end{array}$ & 5 & $\begin{array}{l}\text { Total Variable } \\
\text { Cost }\end{array}$ & Total Fixed Cost & Total Unit Cost & Mark-up Price \\
\hline $\begin{array}{l}\text { Desired } \\
\text { return on } \\
\text { sales }\end{array}$ & $20 \%$ & $936.584 .000,00$ & $1.925 .750 .000,00$ & $\begin{array}{c}1.321 .734 .000,0 \\
0\end{array}$ & $\begin{array}{c}1.652 .167 .500,0 \\
0\end{array}$ \\
\hline
\end{tabular}

Source: Authors (2021)

From Table, The first step taken by researchers in solving this pricing strategy problem is to determine the fixed cost or fixed-cost per year from PT Bumi Perkasa Internasional, the source in determining the fixed costs from PT BPI is the company's financial records and interviews with the owner of the company. The next step is to improve the variable cost calculation format for each product that will be produced by PT BPI. Due to customized products and different according to customer needs, the variable costs of each product will vary and unexpected costs are needed in the calculation of variable costs due to the very long and very detailed production process. By knowing the fixed costs per year and the variable costs of the product to be manufactured, PT Bumi Perkasa Internasional can determine the price of the product using mark-up pricing.

After being able to determine the product price from PT BPI, the last step is the price adjustment strategy. Due to negotiations in the pricing process for their products, PT Bumi Perkasa Internasional often gives discounts to its customers. With a new format that can determine the amount of the total cost for production, the owner can give a discount by taking into account not less than the total unit cost, or it can also reduce the desired return on sales which determines how much profit you want to get in the project. 


\section{Conclusion and Implications}

\section{Website Development}

From the results of the study, improvements in layouts, images, and texts as well as improving the quality of information so that it is easier to read, understand, and provide accurate information on company profiles and websites can improve the assessment of the visual aspects and quality of information. Visual improvements and information quality also increase the brand image of MSMEs when seeing new website because it looks more credible, and professional compared to the old one.

However, further development also needs to be done, such as constantly updating the content contained in the website which is also balanced with the quality of the product, so that the brand image of MSMEs is getting better and expected to influence sales. Utilizing Google advertising services can also be further developed by MSMEs to advertise the website to help marketing activities of PT Bumi Perkasa Internasional.

\section{Pricing Strategy}

It was concluded that in order to develop a pricing strategy, the theory used could be adapted to the MSME total cost and its business process. The form of Expense Budget Plan used can be a process to determine the price with a very mature consideration. This Expense Budget Plan can help MSMEs PT Bumi Perkasa Internasional to get better returns on its products and projects. In the future MSMEs must also conduct evaluations and make changes to better Expense Budget Plan accordance with the conditions and needs of MSMEs in the future, because this Expense Budget Plan is still in the initial development stage.

\section{References}

Adisaputro, Gunawan dan Marwan Asri. (2013). Anggaran Perusahaan. Edisi Kedua. Yogyakarta: BPFE. Arthur A. Thompson, M. A. (2016). Crafting And Executing Strategy: The Quest For Competitive Advantage, concepts and readings. New York: McGraw-Hill Education.

Barney, J. B., \& William, S. H. (2008). Strategic Management and Competitive Advantage. 2nd Edition. USA: Pearson Printice Hall.

Bemmaor, A.C., Mouchoux, D. (1991). Measuring The Short-Term Effect Of In-Store Promotion And Retail Advertising On Brand Sales: A Factorial Experiment. Journal of Marketing Research 28. 202 $-214$.

Blattberg, R.C., Neslin, S.A. (1990). Sales Promotion: Concepts, Methods and Strategies. Prentice-Hall, Englewood Cliffs, NJ.

Bolton, R.N. (1989). The Relationship Between Market Characteristics And Promotional Price Elasticities. Marketing Science 8. 153 - 169.

Chaffey, D., \& Smith P.R. (2016). E-marketing Excellence: Planning and Optimizing Your Digital Marketing. 4th Edition. Routledge Taylor and Francis Group, London and New York.

Claessens, Maximilian. (2015). 3 Major Pricing Strategies - Customer Value-Based Pricing, Cost-Based Pricing, Competition-Based Pricing. Principles of Marketing Explained: Marketing insider. https://marketing-insider.eu/marketing-explained/part-iii-designing-a-customer-driven-marketingstrategy-and-mix/ accessed on 20 December 2020.

Cooper, Donald R \& Schindler, Pamela S. (2006). Business Research Methods 9th Edition. Singapore: McGraw Hill.

Eggert, A. and Ulaga, W. (2002). Customer Perceived Value: A Substitute for Satisfaction in Business Markets. Journal of Business \& Industrial Marketing 17(2/3). 107-18.

Eggert, A., Ulaga, W. and Schultz, F. (2006). Value Creation in the Relationship Life Cycle: A QuasiLongitudinal Analysis. Industrial Marketing Management 35(1). 20-7.

Gamble, J. E., Peteraf, M. A., \& Thompson, A. A. (2015). Essentials of Strategic Management. New York: McGraw-Hill Education.

Gilmore, Audrey. (2011). Entrepreneurial and SME marketing. Journal of Research in Marketing and 
Entrepreneurship. Vol. 13 Iss 2 pp. 137 - 145

Gurel, Emet dan Merba Tat. 2017. SWOT Analysis: A Theoretical Review. Turki: The Journal of International Social Research

Hallberg, Kristin. (2000). A Market-Oriented Strategy for Small and Medium-Scale Enterprises. Discussion Paper 40, International Finance Corporation.

Hinterhuber, A. and Liozu, S. (2012). Is It Time To Rethink Your Pricing Strategy. MIT Sloan Management Review. Vol.53 (4). 69-77

Hutt, Michael dan Thomas W. Speh. (2013). Business Marketing Management B2B. South-Western, Cengage Learning: Canada

Kementerian Koperasi dan UKM. (2019). Perkembangan Data Usaha Mikro, Kecil, Menengah (UMKM) dan Usaha Besar (UB). Retrieved from http://kemenkopukm.go.id accessed on 23 January 2021.

Kotler, P\& Keller, K L. (2016). Marketing Management 15th Ed. USA: Pearson.

Malhotra, N. K. (2010). Marketing Research: An Applied Orientation. Boston: Pearson.

Mclean, Graeme J. (2017). Investigating the Online Customer Experience - a B2B perspective. Marketing Intelligence \& Planning Journal. Emerald: USA

McPheat, Sean. (2011). Developing Internet Marketing Strategy. United States of America: Ventus Publishing

Milton F. Usry dan Adolph Matz. (1987). Cost Accounting Planning and Qontrol 8th Edition. South Western Publishing Co: Ohio.

Myers, M.B. (2004). Implications Of Pricing Strategy-Venture Strategy Congruence: An Application Using Optimal Models In An International Context. Journal of Business Research. Vol. 57 No. 6. pp. 591-600.

Osterwalder, A. \& Pigneur, Y. (2010). Business Model Generation: A Handbook for Visionaries, Game Changers, and Challengers. New Jersey: John Willey \& Sons.

Rayport, J. F., \& Jaworski, B. J. (2001). Introduction to E-commerce. New York: McGraw-Hill

Sen, R. (2005). Optimal Search Engine Marketing Strategy. International Journal of Electronic Commerce, $10(1), 9-25$.

Smith, K. (2007). What is digital marketing? [Web log message]. Retrieved from http://digitalmarketing101.blogspot.com/2007/10/what-is-digital-marketing.html accessed on 20 January 2021.

Tjitrosidojo, Soemardjo. (1980). Bunga Rampai Menuju Pemeriksaan Pengelolaan (Manajemen Auditing). Van Hoeve Jakarta: Ichtiar Baru.

Wang, Wei-Lin, Edward C, Bobby C dan Ebru U. (2017). B2B Content Marketing For Professional Services: In-Person Versus Digital Contacts. Industrial Marketing Management Journal.Elsevier: USA

World Bank. (2019). Small and Medium Enterprises (SMES) Finance. Retrieved from http://worldbank.org accessed on 15 April 2021.

Wuollet, J. (2013). Pricing strategy and revenue models: A multiple case study from the IT service sector in Finland. 